Goldschmidt 2021 Abstract

https://doi.org/10.7185/gold2021.4144

\section{brGDGTs and isotopic records for Lake Ayrag: implications for climate, vegetation and human impact history of the Mongolian Plateau.}

LUCAS DUGERDIL ${ }^{1,2}$, GUILLEMETTE MÉNOT ${ }^{1}$, ODILE PEYRON $^{2}$, ISABELLE JOUFFROY-BAPICOT ${ }^{3}$, ANNE-LISE DEVELLE $^{4}$, INGRID ANTHEAUME ${ }^{1}$, SALOMÉ ANSANAYALEX $^{1}$, BORIS VANNIÈRE ${ }^{3}$, BAZARTSEREN BOLDGIV ${ }^{5}$, MATTHEW MAKOU ${ }^{1}$, VINCENT GROSSI ${ }^{6}$, JULIA $\mathrm{UNKELBACH}^{7}, \mathrm{HERMANN} \mathrm{BEHLING}^{7}$, JÉRÔME MAGAIL $^{8}$, MARY ROBLES $^{2}$ AND SÉBASTIEN JOANNIN ${ }^{2}$

${ }^{1}$ LGLTPE, Univ Lyon, ENS de Lyon, Université Lyon 1, CNRS

${ }^{2}$ Université de Montpellier, ISEM

${ }^{3}$ Laboratoire Chrono-environnement, UMR 6249 CNRS

${ }^{4}$ Université Grenoble Alpes-Université Savoie Mont BlancCNRS-EDYTEM, UMR 5204

${ }^{5}$ Ecology Group, Department of Biology, School of Arts and Sciences, National University of Mongolia

${ }^{6}$ LGLTPE,

${ }^{7}$ Department of Palynology and Climate Dynamics, Albrechtvon-Haller-Institute for Plant Sciences, University of Goettingen

${ }^{8}$ Musée d'anthropologie préhistorique de Monaco

Presenting Author: lucas.dugerdil@ens-lyon.fr

Pollen transfer functions (TF) are currently one of the most reliable methods for paleoclimate modelling of continental temperature and precipitation. Over the last few decades, molecular biomarkers such as branched glycerol dialkyl glycerol tetraethers (brGDGTs) have provided a powerful alternative to TF. In extremely arid environments such as the mountainous areas ranging from northern Arid Central Asia (ACA) to the Mongolian Plateau (MP), a coupled globally vs. locally calibrated pollen-brGDGT climate approach has been tested to provide robust estimates of Holocene climate and environmental changes. This multi-proxy approach was applied to the Lake Ayrag record, Arkhangai. The 4,000 year cal BP sequence also underwent element and isotopic bulk chemistry and Non-Pollen Palynomorph (NPPs) analyses in order to better understand the lake system and human impact dynamics.

While the global calibrations (both for pollen and brGDGTs) display a steady millennial-scale cooling, the local calibration highlights centennial-scale climate oscillations such as the Little Ice Age (LIA), the Warm Medieval Period (WMP), the Dark Ages Cold Period (DACP), the Roman Warm Period (RWP) and the $3.5 \mathrm{kyr}$ cooling event. Climate oscillations are discussed with regard to the main Mongolian historical occupation events documented by pastoralism proxies.

Both pollen and biomarkers show anti-correlated trends between temperature and precipitation: over the last 4,000 yrs cal $\mathrm{BP}$, the warm periods (WMP, RWP) were dry and the cold periods (LIA, DACP, 3.5 kyrs) were wetter. Thus, the East Asian Summer Monsoon (EASM, i.e. warm and wet conditions dominant in summer) seems not to have influenced central Mongolian climate during the Late Holocene, which stayed dominated by the Westerlies / Siberian Highs cells conflict.

A comparison between the Ayrag record and other sites from the Baikal area to the Loess Plateau suggests that the EASM front oscillated since the Holocene Optimum. Its consequences for the ACA and MP are determinant to improve our understanding of climate changes' impacts on human societies. A climate synthesis following the same approach (brGDGT vs. pollen-inferred climate) on ACA records should help us to better draw the climate system map paced by centennial to millennial oscillations and their consequences for human societies.

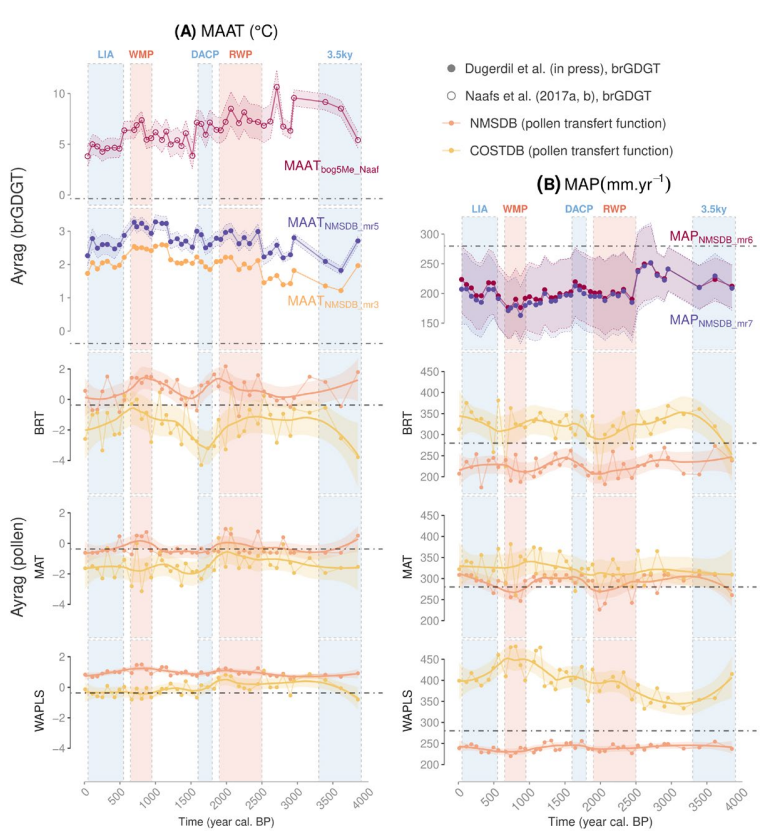

